\title{
MICROEARTHQUAKES UNDER AND ALONGSIDE ICE STREAM B, ANTARCTICA, DETECTED BY A NEW PASSIVE SEISMIC ARRAY
}

by

\author{
D.D. Blankenship, S. Anandakrishnan, J.L. Kempf and C.R. Bentley
}

(Geophysical and Polar Research Center, University of Wisconsin-Madison, Madison, WI 53706, U.S.A.)

\begin{abstract}
A new seismographic array with a band width of $500 \mathrm{~Hz}$ per channel and a dynamic range of $96 \mathrm{~dB}$ was developed for detecting natural events on glaciers. It was first deployed on ice stream B during the 1985-86 austral summer. The network consists of nine solar-powered seismographs, each monitoring three components of ground motion. Each of the seismographs is connected by up to $4 \mathrm{~km}$ of fiber-optic cable to a central node where seismic events are both detected and recorded. During $85 \mathrm{~h}$ of passive seismic monitoring on ice stream B, 25 microearthquakes were observed. Sixteen of these events were associated with shallow crevassing, mostly near the margins, although not within the zones of extreme shearing that bound the ice streams. Nine microearthquakes were associated with low-angle thrusting near the base of the ice stream. The principal initial result of these passive seismic studies is the demonstration that virtually none of the energy dissipated beneath ice stream B takes place through brittle fracture near the base. Nevertheless, fracture associated with microearthquakes may play a significant role in sub-glacial erosion.
\end{abstract}

\section{INTRODUCTION}

The stability of the marine ice sheet of West Antarctica is one of the fundamental unsolved problems in glaciology. A first approach to understanding the dynamics of the West Antarctic ice sheet is to understand the dynamics of the so-called "Ross ice streams" (Bentley in press) that drain the majority of its ice (Fig.1). Recent advances in geophysical remote sensing (Bentley and others 1987) have assisted in comprehending the processes that control these ice streams as well as the nature of their interaction with the Ross Ice Shelf. To date, active seismology and radar have been the primary investigative tools; this paper discusses the first application of passive seismology to problems of ice-stream dynamics in West Antarctica.

The earlier use of passive seismology has been effective only to study the stress regime of Athabasca Glacier in North America (Neave and Savage 1970); no studies prior to ours have been undertaken in Antarctica. The work of Neave and Savage (1970) used a seismic array with a band width of several hundred $\mathrm{Hz}$ and a dynamic range of $35 \mathrm{~dB}$; only the vertical component of ground motion was monitored. The microearthquakes observed in their investigation had a dominant period of $10 \mathrm{msec}$ and were caused by crevassing within $60 \mathrm{~m}$ of the surface of the glacier.

Serious seismic studies of basal sliding have not been possible because seismic events associated with fracture or slip at the base of a glacier have not been identified conclusively. The seismic array deployed by Neave and Savage (1970) was theoretically large enough to locate microearthquake sources associated with basal sliding, but none was observed. It is possible that the area of rupture or slip associated with basal sliding of Athabasca Glacier was smaller than that associated with the crevassing near the

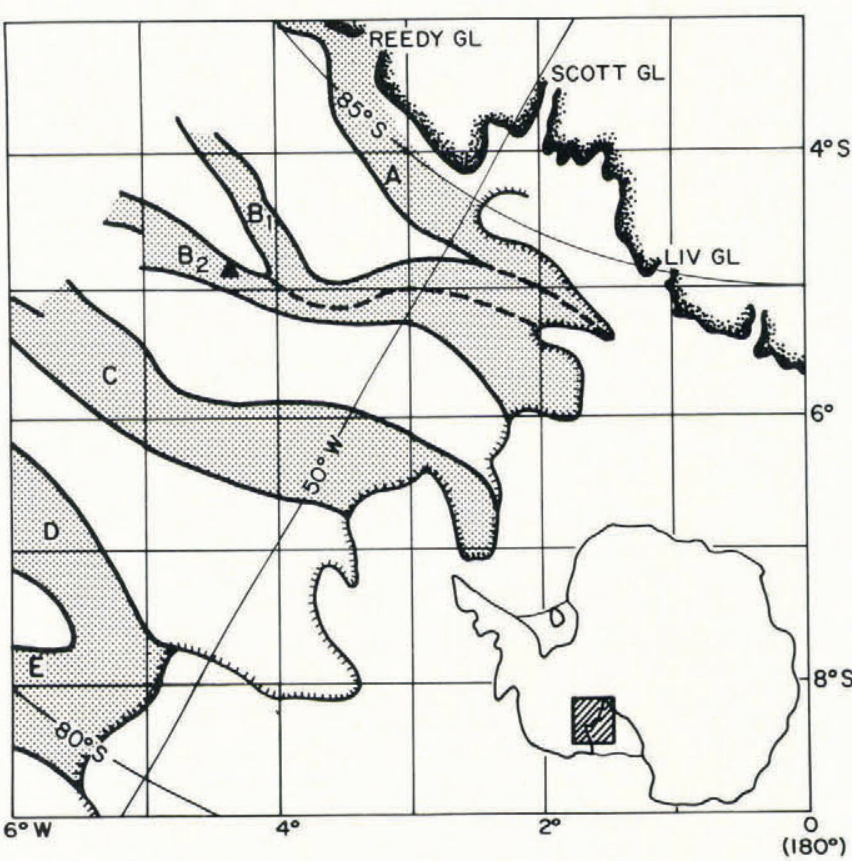

Fig.1. The Siple and Gould Coasts of West Antarctica. The "Ross ice streams" are lettered A, B $, \mathrm{B}_{2}, \mathrm{C}, \mathrm{D}$, and $\mathrm{E}$. The triangle denotes the location of "Upstream B" camp. Simplified from Shabtaie and Bentley (1986).

surface. Because the amplitude of the lower-frequency components of a seismic event is proportional to the size of the rupture area (Aki and Richards 1980, p.811) the limited dynamic range of the seismic array deployed by Neave and Savage might have made it difficult to detect seismic events associated with both near-surface crevassing and basal sliding. At the same time, because the upper-limit frequency of the seismic energy (i.e. the corner frequency) is inversely proportional to some power of the size of the rupture area (Aki and Richards 1980, p.821), most of the energy of any tremors caused by basal sliding might have occurred at frequencies above the upper limit of detectability for their seismic array.

To use passive seismology for studies of the internal stresses and basal sliding of the Ross ice streams, we have developed a seismic array that possesses much larger dynamic range (at least $96 \mathrm{~dB}$ ) and band width $(500 \mathrm{~Hz})$ than previously used in glacier studies. In this paper the technical aspects of this newly developed passive seismic array are described and the results of its first deployment, on ice stream $\mathrm{B}$, are reviewed.

\section{DEVELOPMENT OF THE SEISMIC ARRAY}

The increased dynamic range and band width required for the new passive seismic array were achieved by 
incorporating recent advances in both analog-to-digital conversion and data-transmission technology. The array (Fig.2) comprises nine "remote" stations, at which three components of ground motion are digitized, connected by fiber-optic links to a "home" unit where the seismic information is reconstructed. The home unit is attached to a data logger (also developed at the Geophysical and Polar Research Center) where detection algorithms are applied to

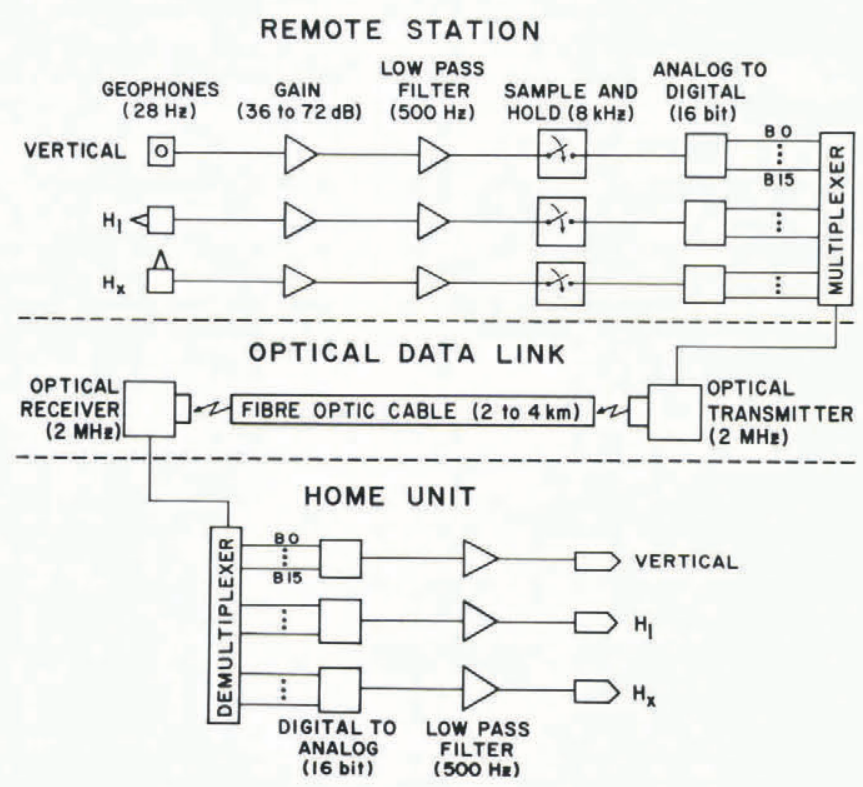

Fig.2. Schematic representation of the three primary elements of the passive seismic array developed by the Geophysical and Polar Research Center. $\mathrm{H}_{1}$ and $\mathrm{H}_{\mathrm{x}}$ are the horizontal components of ground motion that are parallel and transverse to ice flow, respectively.

the digitized seismic signals and detected events are recorded.

Three geophones, one each for the vertical and two horizontal components of ground motion, are connected to each remote station. These geophones are characterized by a natural frequency of $28 \mathrm{~Hz}$ and a frequency response that is flat to at least $420 \mathrm{~Hz}$. Low-noise pre-amplifiers $(\approx 0.1 \mu \mathrm{V}$ r.m.s.) are utilized at the input stages of the remote station. The pre-amplifiers are followed by amplifiers with a gain that can be varied between 36 to $72 \mathrm{~dB}$ in $12 \mathrm{~dB}$ steps. Four poles of a Butterworth low-pass filter with a corner frequency of $500 \mathrm{~Hz}$ are used to eliminate any spurious high-frequency noise. The amplified and filtered signal from each geophone is sampled at $8 \mathrm{kHz}$ by a precision-integrated sample-and-hold chip. The sampled signal is digitized by a 16 bit analog-to-digital converter. As the sampling frequency is four octaves above the corner frequency of the filter, the signal is $96 \mathrm{~dB}$ down at the sampling frequency and aliasing is eliminated. The digitized sample (16 bits) plus a header of 8 bits containing gain information is multiplexed with the corresponding 24 bits from the other two channels in each remote station. The power for each remote station is derived from a $1 \mathrm{~m}^{2}$ (10 W) solar panel; a $12 \mathrm{~V}$ lead-acid battery provides voltage regulation and back-up power.

Each optical link uses a $2 \mathrm{MHz}$ clock and an optical transmitter with internal Manchester encoding to transmit data from the remote stations to the home unit. The bit stream produced by the remote stations modulates the light power of the transmitter. This modulated light is coupled to a fiber-optic cable with a step-index wave guide $(100 \mu \mathrm{m}$ core $/ 140 \mu \mathrm{m}$ cladding). The central wave guide in the cable is surrounded by a loose protective buffer, Kevlar braid runs the length of the cable for tensile strength, and the outer jacket is polyurethane. The optical attenuation in the wave guide is $\approx 4 \mathrm{~dB} / \mathrm{km}$ and the loss in each coupling is about $2 \mathrm{~dB}$, so for a $2 \mathrm{~km}$ optical link, there is a $12 \mathrm{~dB}$ loss, and for a $4 \mathrm{~km}$ link, a $22 \mathrm{~dB}$ loss. An optical receiver with internal Manchester decoding receives the data at the home unit. The difference in light-power output by the transmitter and light-power sensitivity of the receiver (flux budget) is about $27 \mathrm{~dB}$, i.e. a loss of up to $27 \mathrm{~dB}$ in the fiber-optic cable could be sustained without destroying the integrity of the link.

At the home unit, the optical receivers reproduce the bit stream as well as the clock from the remote stations. This bit stream is de-multiplexed into three channels and re-converted to analog form at $8 \mathrm{kHz}$ by a 16 bit digitalto-analog converter. Four poles of a low-pass Butterworth filter with a corner frequency of $500 \mathrm{~Hz}$ are used for smoothing the analog wave form on each channel. A reproduction of the seismic information at each of the remote stations is then fed to a data logger, where the data are digitally monitored and events are detected and recorded.

\section{DEPLOYMENT OF THE SEISMIC ARRAY}

Commencing in 1983, the University of Wisconsin joined the Ohio State University, NASA, and the University of Chicago in an intensive study of the West Antarctic ice sheet near the Siple and Gould Coasts (Fig.1). As part of this cooperative investigation, the newly developed passive seismic array was deployed on ice stream B during the 1985-86 austral summer.

The array (Fig.3) was positioned near the center of the ice stream. The nine remote stations were distributed on a

\section{UPSTREAM B PASSIVE SEISMIC ARRAY}

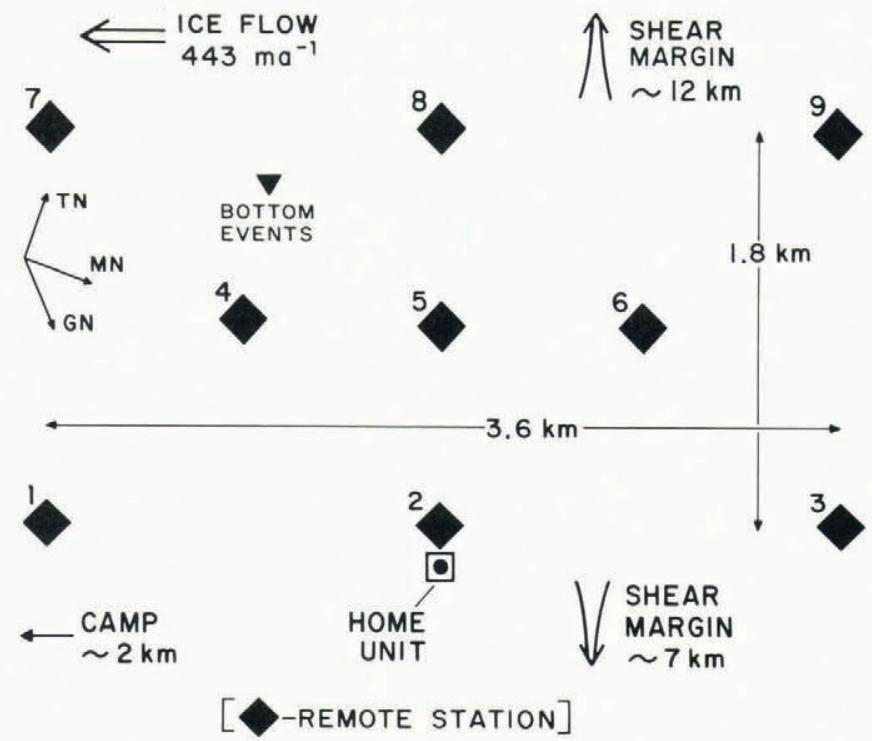

Fig.3. Schematic representation of the new passive seismic array as it was deployed on ice stream B. The numbered diamonds are the remote stations. TN, MN, and GN denote true north, magnetic north, and grid north, respectively.

rectangle measuring $1.8 \mathrm{~km}$ by $3.6 \mathrm{~km}$, with the long dimension of the array parallel to the direction of ice movement. At each remote station, one horizontal geophone was placed parallel to the ice flow and the other transverse to the ice flow. The array was tested and calibrated by detonating $0.9 \mathrm{~kg}$ explosive charges at 30 surveyed locations within it.

The passive seismic array was maintained for 3 weeks during which $85 \mathrm{~h}$ of microearthquake monitoring were achieved (Fig.4). Because of the "cultural" noise emanating from the "Upstream B" camp, monitoring was generally possible only between midnight and $08.00 \mathrm{~h}$ (McMurdo local 
MICROEARTHQUAKES AT UPSTREAM B

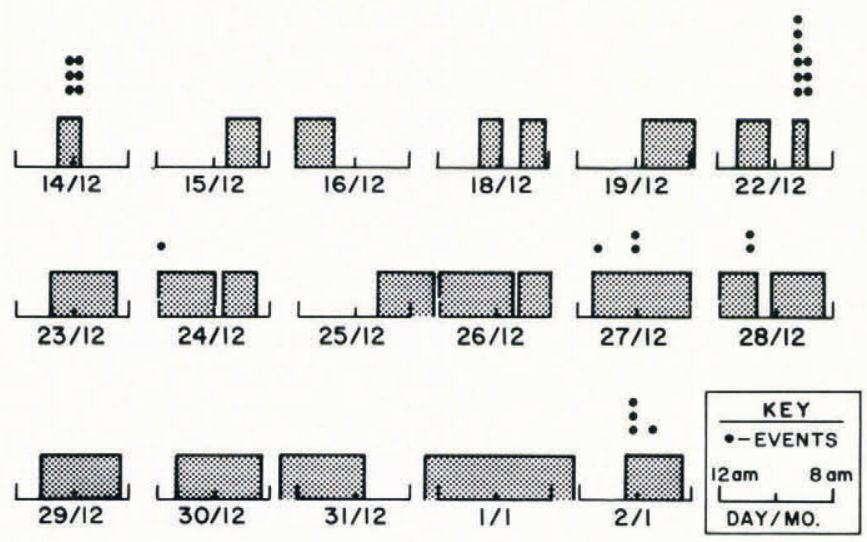

Fig.4. Calendar showing periods (stippled blocks) of seismic monitoring on ice stream B during 1985-86. Each individual segment is marked with the day/month and with tick marks at $00.00,04.00$, and $08.00 \mathrm{~h}$ McMurdo time. Seismic events are indicated by dots.

time). During the monitoring, the data logger continuously digitized each of the 27 output channels of the home unit; it also applied a threshold detector to one of these channels. A recording was triggered when the absolute value of the signal from the vertical channel of a pre-selected remote station exceeded a level set at about $0.5 \%$ of the total dynamic range of the array. Remote stations $2,4,6$, and 8 were used at various times for event detection. When triggering occurred, digitized seismic signals from all remote stations for the $5 \mathrm{~s}$ interval starting $2 \mathrm{~s}$ before the triggering were recorded on a removable disk cartridge.

\section{OBSERVATIONS OF MICROEARTHQUAKES}

During the $85 \mathrm{~h}$ of seismic monitoring 25 microearthquakes were detected and recorded (Fig.4). Sixteen of these events were true "icequakes" associated with crevassing, presumably near the surface. Fig.5 depicts a typical icequake; the first arrivals are $\mathrm{P}$-waves (compressional waves) that are characteristically emergent. The icequakes of ten occurred in groups of up to four events typically 1-5 min apart. Because of the frequent absence of clear S-wave (shear-wave) arrivals, precise locations of the sources for the icequakes (particularly their depths) will require careful numerical inversion of the $\mathrm{P}$-wave travel times. Preliminary graphical analysis of the P-wave travel times for these icequakes shows that most of their sources were within $10 \mathrm{~km}$ of the seismic array and were associated with open crevasses near the shear margins of the ice stream that were observed on aerial photography by Vornberger and Whillans (1986). Surprisingly, none of the sources were located in the "chaotic zones" of intense shearing that bound the ice stream.

The most interesting phenomenon observed was a swarm of nine very small microearthquakes occurring just a few minutes apart on 22 December (Fig.4). The arrivals from one of these events are depicted in Fig.6; other microearthquakes in the swarm yielded very similar seismograms. All of the P-wave and many of the S-wave arrivals associated with these events are quite distinct.

Assuming the ice column is both vertically and laterally homogeneous, a simple iterative analysis of the P-wave and S-wave travel times places the foci of seven of these microearthquakes within several tens of meters of the base of the ice at the location indicated in Fig.3. The locations were calculated using a P-wave velocity in the ice of $3.83 \mathrm{~km} / \mathrm{s}$ and an S-wave velocity of $1.94 \mathrm{~km} / \mathrm{s}$, both obtained by Blankenship and others (in press), as well as an ice thickness of $1080 \mathrm{~m}$ determined by Rooney and others (in press). The question of whether these foci are within the ice, sub-glacial till (reported by Blankenship and others

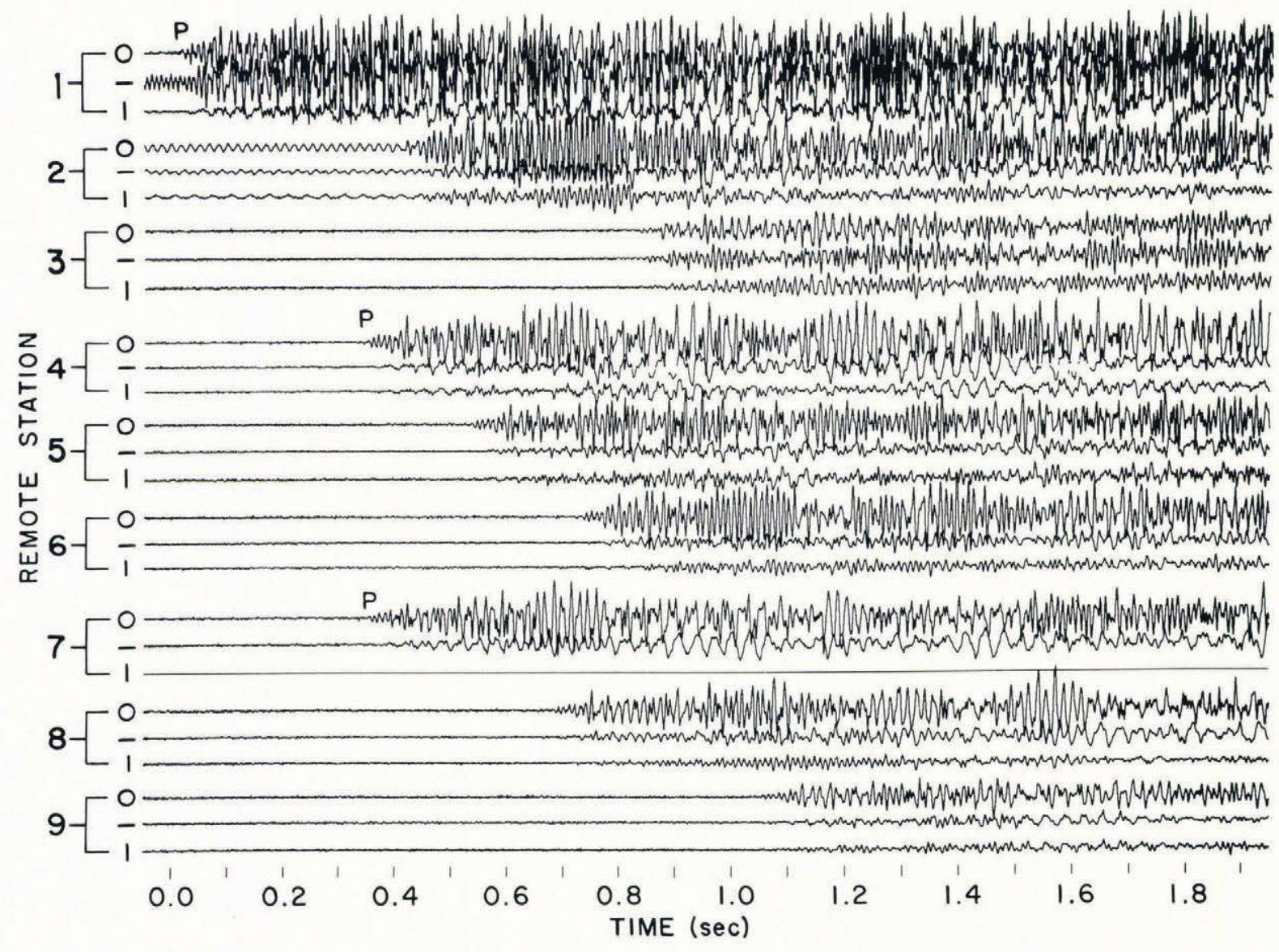

Fig.5. Microearthquake associated with shallow crevassing near the shear margins of ice stream B. The vertical component of ground motion is denoted by $\mathrm{O} ;-$ and I are horizontal components parallel and transverse to ice flow, respectively. P-wave arrivals at the first of each group of three stations are indicated. 
(1986; in press), and Alley and others (1986; in press)) or bedrock beneath the till, is important to the analysis of erosional mechanisms of ice stream $B$ and will be addressed in future analyses.

Assuming these basal events arise from a double-couple source along some fault plane, the nodes and antinodes of the radiation pattern for the $P$-wave first motions (see Fig.6) can be used to infer the geometry of this fault plane. Aki and Richards (1980, p.82) show that a maximum compression and a maximum dilatation will occur at $45^{\circ}$ angles to the fault-plane normal that has its origin at the source. These antinodes lie in a plane defined by the normal and slip vector; the intervening node lies along the fault-plane normal. The compressional antinode will lie on the side of the node that is in the direction of the slip of the near side of the fault; the dilatational antinode will lie on the opposite side. From Fig.6 we see that the P-wave first motion is up (representing compression) at stations 1 and 7 downstream of the bottom events (Fig.3), whereas at the other stations it is down (representing dilatation). The P-wave first motion at station 4 is quite small (the gain on the vertical channel at station 4 is higher than on the other vertical channels), implying that it lies close to a node in the P-wave radiation pattern. Because the source is known to lie nearly beneath station 4 , we see from the description above that these observations are consistent with a fault plane that is nearly horizontal, and with a slip of the upper wall of the fault that is parallel to the direction of ice flow. The source location and fault-plane geometry for this event imply that it arises from low-angle thrust faulting near the base of the ice stream. Because we believe that this thrusting may be related to erosion at the base of the till as proposed by Rooney and others (in press), we are currently in the process of obtaining more precise fault-plane solutions for the nine-event swarm by formally inverting both the $\mathrm{P}$-wave and $\mathrm{S}$-wave radiation patterns.

Another interesting feature, best depicted on the seismogram for remote station 5 (Fig.6), is the possibility of shear-wave splitting; the S-wave polarized transverse to ice flow travels approximately $2 \%$ faster than the $\mathrm{S}$-wave polarized parallel to flow. One of the authors (DDB) has observed comparable anisotropy for S-waves recorded during seismic reflection experiments near "Upstream B" and a detailed analysis will be presented in a future paper.

A significant result of this first deployment of a passive seismic array on an active Antarctic ice stream is the paucity of microearthquakes whose sources are near the base of the ice. The seismic energy released by each of the nine bottom events can be calculated directly from the seismograms. Robin (1958) gives the energy per unit area $\left(\mathrm{E}_{\mathrm{S}}\right)$ for a seismic pulse measured by a detector near the surface as

$$
\mathrm{E}_{\mathrm{S}}=1 / 8 \rho \lambda \mathrm{V}^{2}
$$

where $\rho$ and $\lambda$ are, respectively, the density of the medium and the seismic wavelength, and $\mathrm{V}$ is the maximum particle velocity. At the position of our detector $\rho$ was $\approx 400 \mathrm{~kg} / \mathrm{m}^{3}$ (Alley personal communication, 1986) and the $\mathrm{P}-$ and S-wave speeds were about 1000 and $600 \mathrm{~m} / \mathrm{s}$ (Blankenship and others in press), respectively. For typical $P-$ and S-waves arriving at stations 5, 6, and 8 (e.g. Fig.6), we obtained $\mathrm{V}=2 \times 10^{-7} \mathrm{~m} / \mathrm{s}$ and $\lambda=10 \mathrm{~m}$ for the narrower initial $\mathrm{P}$-wave pulse, $\mathrm{V}=1 \times 10^{-7}$ and $\lambda=25 \mathrm{~m}$ for the broader P-wave pulse, and $V=1 \times 10^{-7}$ and $\lambda=15$ for each S-wave component (i.e. one transverse and one parallel to flow). Thus for each microearthquake, the total $E_{s}$ in the P- and S-waves is about $0.5 \times 10^{-10} \mathrm{~J} / \mathrm{m}^{2}$. Since stations 5 , 7, and 8 were each approximately $1 \mathrm{~km}$ from the epicenters (Fig.3), the total seismic energy for the nineevent swarm was $\approx 10^{-2} \mathrm{~J}$. Using a typical seismic efficiency of $1 \%$ (Jaeger and Cook, 1970), the total energy released by these basal events seems to be about one Joule. However, because in the above calculation we have ignored both losses due to internal friction and likely asymmetry in the $\mathrm{P}$ - and $\mathrm{S}$-wave radiation patterns, we believe that the total

$1-[$

$P$

$2-\tau$

$3-5$

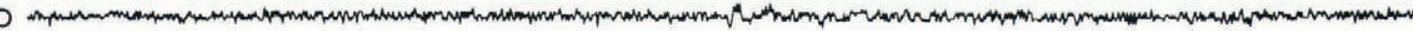
[ 1 1

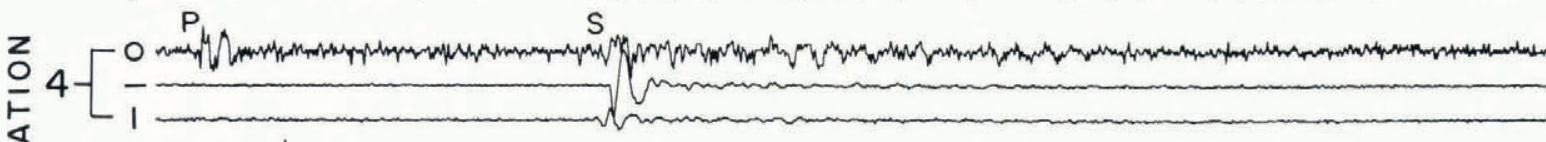
is $5-\left[\frac{1}{0}\right.$

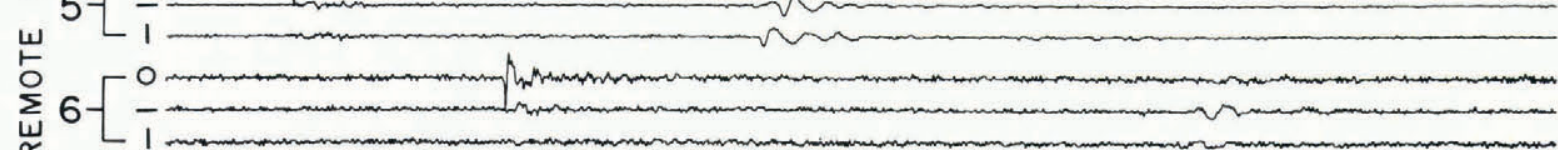
幽

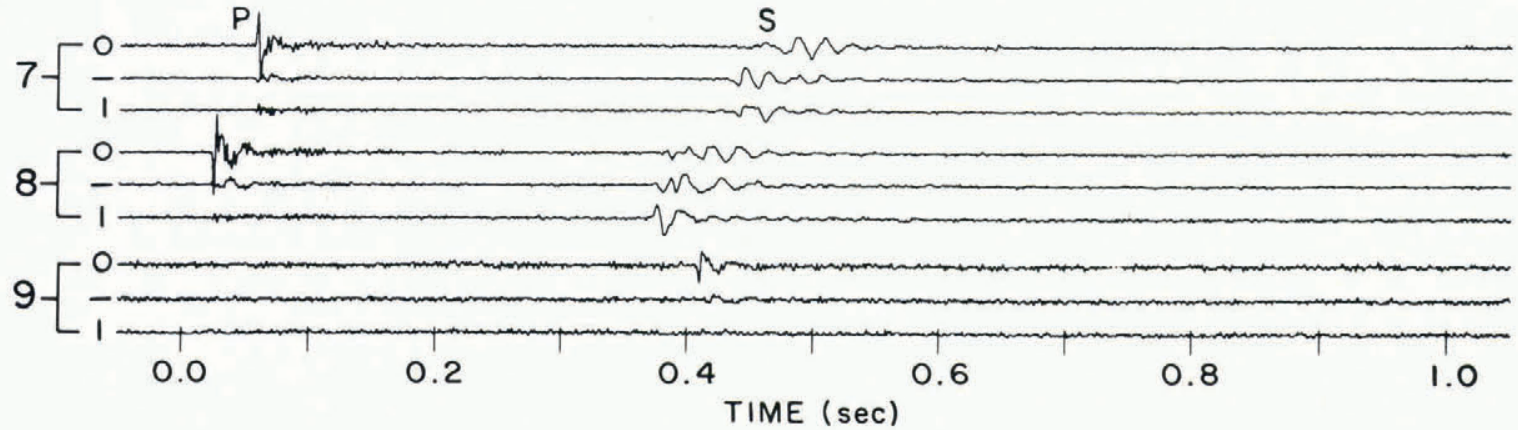

Fig.6. Microearthquake associated with low-angle thrusting near the base of ice stream B. The vertical component of ground motion is denoted by $\mathrm{O} ;-$ and $\mid$ are the horizontal components parallel and transverse to ice flow, respectively. P-wave and S-wave arrivals at the first of each group of three stations are indicated. The gains of individual channels have been adjusted to increase the visibility of arrivals. 
energy released by faulting at the base of the ice stream during our period of observation could have been as much as 10 Joules.

The energy released by basal faulting can be compared with the total energy dissipated by glacier sliding. The latter energy, $\mathrm{E}$, is given by

$$
E=u_{s} \tau_{b} T A
$$

where $u_{s}$ is the sliding velocity, $\tau_{b}$ is the basal shear stress, $T$ is the elapsed time, and $A$ is an appropriate basal area. If for $A$ we take $3 \times 10^{6} \mathrm{~m}^{2}$ (as an approximate area of basal coverage by the passive seismic array), $\mathrm{T}=0.01 \mathrm{a}$ (for the 85 hours of seismic monitoring), $\mathrm{u}_{\mathrm{s}}=$ $440 \mathrm{~m} \mathrm{a} \mathrm{a}^{-1}$ (Whillans and others in press) and $\tau_{\mathrm{b}}=$ $2 \times 10^{4} \mathrm{~Pa}$ (from measurements of ice thickness and surface slope given by Shabtaie and Bentley (in press)), we obtain $E \simeq 10^{11} \mathrm{~J}$. Thus the energy released by rupture at the base of ice stream $B$ is at most the order of one part in $10^{10}$ of the energy dissipated in ice stream movement. Even though our short period of observation could have been unrepresentative, it seems clear that brittle fracture plays no direct role in the dynamics at the base of ice stream $B$. However, if the basal microearthquakes arise from fracture of the lithified sediments that have been shown to exist directly beneath the sub-glacial till (Rooney and others in press), they could be an important contributor to basal erosion.

\section{CONCLUSIONS}

A new passive seismic array that uses new technology to provide both a broad band width and a large dynamic range has been developed and deployed on an active Antarctic ice stream. Microearthquakes that occurred near the shear margins and close to the base of the ice stream were detected by this new array and digitally recorded. Although analysis of these events is still at a preliminary stage, a principal result of this deployment is that, at least for ice stream B, brittle fracture dissipates very little of the energy associated with basal sliding; however, it may play an important role in sub-glacial erosion.

\section{ACKNOWLEDGEMENTS}

We wish to thank L A Powell, B D Karsh, D R Novotny, and $P$ Kinnerk for their engineering assistance, S T Rooney and K Kilalea for help with the field work, and $A$ N Mares and $J$ Gallagher for manuscript and illustration preparation. We are particularly indebted to B R Weertman, S T Rooney, and R B Alley for many helpful discussions. This work was supported by the US National Science Foundation under grant DPP-8412404. This is contribution No. 462 of the Geophysical and Polar Research Center, University of Wisconsin-Madison.

\section{REFERENCES}

Aki K, Richards P 1980 Quantitative seismology. San Francisco, W.H. Freeman

Alley R B, Blankenship D D, Bentley C R, Rooney S T 1986 Deformation of till beneath ice stream B, West Antarctica. Nature 322(6074): 57-59

Alley R B, Blankenship D D, Bentley C R, Rooney S T In press Till beneath ice stream B. 3. Till deformation: evidence and implications. Journal of Geophysical Research

Bentley C R In press Antarctic ice streams: a review. Journal of Geophysical Research

Bentley C R and 6 others 1987 Remote sensing of the Ross ice streams and adjacent Ross Ice Shelf, Antarctica. Annals of Glaciology 9: 20-29

Blankenship D D, Bentley C R, Rooney S T, Alley R B 1986 Seismic measurements reveal a saturated, porous layer beneath an active Antarctic ice stream. Nature 322(6074): 54-57

Blankenship D D, Bentley C R, Rooney S T, Alley R B In press Till beneath ice stream B. 1. Properties derived from seismic travel times. Journal of Geophysical Research
Jaeger J C, Cook N G W 1970 Fundamentals of rock mechanics. London, Chapman and Hall

Neave K G, Savage J C 1970 Icequakes on the Athabasca Glacier. Journal of Geophysical Research 75(8): 1351-1362

Robin G de Q 1958 Glaciology 3. Seismic shooting and related investigations. Norwegian-British-Swedish Antarctic Expedition, 1949-52. Scientific Results 5

Rooney S T, Blankenship D D, Alley R B, Bentley C R In press Till beneath ice stream B. 2. Structure and continuity. Journal of Geophysical Research

Shabtaie S, Bentley C R 1986 Ice streams and grounding zones of West Antarctica and the Ross Ice Shelf. (Abstract.) Annals of Glaciology 8: 199-200

Shabtaie S, Bentley C R In press West Antarctic ice streams draining into the Ross Ice Shelf: configuration and mass balance. Journal of Geophysical Research

Vornberger P L, Whillans I M 1986 Surface features of ice stream B, Marie Byrd Land, West Antarctica. Annals of Glaciology 8: 168-170

Whillans I M, Bolzan J, Shabtaie S In press Velocity of ice stream B, Antarctica, and its mass balance. Journal of Geophysical Research 